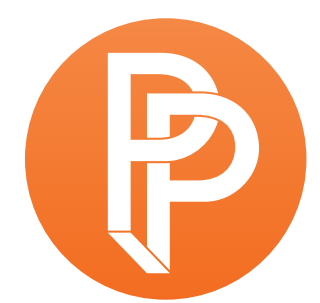

PERFORMANCE

PHILOSOPHY

\title{
ONE PART WATER, TWO PARTS STARCH: PERFORMING OOBLECK AS POLITICALRESISTANCE
}

\author{
JOSH WIDERA CALIFORNIA INSTITUTE OF THE ARTS
}

Oobleck is two things: a non-Newtonian fluid, a mixture of cornstarch and water showing properties of both a liquid and a solid; and an invention by Dr. Seuss, an odd green weather occurrence whose fluid, adhesive, and elastic attributes manage to threaten the entire state apparatus of the "Kingdom of Didd." Re-viewing the children's book Bartholomew and the Oobleck, and in light of its starch-and-water namesake, I argue that we can learn an insurrective strategy of political resistance from its performativity.

\section{Double Oobleck}

Theodor Geisel is probably one of the most celebrated names in children's literature. If you enter a family home, especially in the United States, chances will be high that you will come across one of his books, written under the pen name "Dr. Seuss". While an undoubted staple in a lot of young anglophones' reading experiences, he is somewhat less important in other parts of the world. I grew up in a small town in Germany where Dr. Seuss carried no cultural or personal significance. Horton, the Lorax, and the Grinch are no fixtures of the public conscious. For all I know, I might have well gone about the business of growing up without ever coming across his stories, if it was not for my next door neighbour, Frau (Mrs.) Grüner. Frau Grüner was an older lady, either in or just before retirement, who had been an English teacher all her life. Her house and ours shared a driveway and the gardens in the back ran along the same knee-high chain-link fence. You could 
sometimes hear the stairs creak when Frau Grüner or her husband moved around the house. When we were on holiday, Grüners would-indulgently-look after our cat. And when they were gone, my mother would go over to water the plants.

Shortly after I had begun learning English in school, it must have been third grade or fourth, Frau Grüner started to move, little by little, a whole wealth of books from their place to ours-leftovers, perhaps from her own children, or from her time as a teacher. And thus I slowly started to accumulate books for language learners and simple children's literature in English. Among them, too, a few works by Dr. Seuss. While writing this review and talking about it to some of my American friends, I realise that the book I am going to speak about is actually not particularly well-known. Most people do not recall reading Bartholomew and the Oobleck. It might be because it is one of Geisel's few prose works, not written in the anapestic tetrameter he is so famous for. It might be because Bartholomew is not as fun of a protagonist as the Cat in the Hat. I do not know. For me, all of Dr. Seuss came in the same box. And in fact, until quite recently, I had all but forgotten. ${ }^{1}$

At some point in 39 Microlectures in the Proximity of Performance, Matthew Goulish writes about breaking down traditional dichotomies of art and criticism, passion and intellect, among others:
Take for example the problem of glass. What is glass? Until recently, glass was considered a mostly transparent solid. It behaved like a solid; if struck, it shattered. But then, in the ancient cathedrals of Europe, it was observed that the tops of windows let in more light than the bottoms. A simple measurement proved that a window of once uniform thickness had grown thicker at the bottom and thinner at the top. Only one explanation exists for this phenomenon. Glass flows in the direction of the pull of gravity, exhibiting the behavior of a liquid. Thus, one cannot conclusively define glass without the inclusion of time. At any given moment, glass is a solid, but over a period of one thousand years, it is a liquid. The problem of glass forces us to accept the inaccuracy of the traditional distinctions of solid or liquid. While the qualities of solidity and liquidity retain their difference, glass in fact is both, depending on the duration of observation, thus proving that these two states inextricably coexist [...].
As creative and critical thinkers, we may find it rewarding to attempt works of criticism, which, over time, reveal themselves as works of art, thus following the example of glass. $(2000,44)$

This story of medieval glass flowing downwards has been debunked. Some glass might theoretically sag at room temperature, but only after about $10^{33}$ years ("Cathedral Glass Myth" 1998) - the universe, by comparison, is just over 13.8 billion years old, a fraction of that time. Additionally, there are examples of glass, from ancient Egypt for example, not showing those qualities. Rather, the explanation lies in the production process: "At that time, glassblowers created glass cylinders that were then flattened to make panes of glass. The resulting pieces may never have been uniformly flat" (Curtin 2007). Even though Goulish's example of glass has been shattered, as he himself has noted (Goulish 2015), its implications are still intact. Goulish reconsiders his example and writes instead: 
Now I will say it this way. The glass retains the material memory of its brief life as a liquid-the slightest waveform, suspended. Duration doubles a substance. In the function of the solid (the window) remains the antithetical trace of the liquid moment (the pool with its flow). Allow the memory of the creative in the function of the critical. $(2015,133)$

And so, I am still left with a flaming sense of excitement about two things: firstly, criticism becoming art with the inclusion of time. Secondly, the existence of things that are at once two states of matter. As it turns out, those actually exist: Non-Newtonian fluids are fluids that exhibit both liquid and solid attributes. Chemico-physical misfits. Perhaps the most famous example of misbehaving substances: oobleck.

Oobleck, also sometimes referred to as ooze, is a substance that can easily be made at home. Many schoolchildren might have at some point experimented with it. Its recipe is simple: two parts starch (cornstarch for example), one part water. You can submerge your hand in it and pull it back out, and the thick ooze will drip off your fingers, not dissimilar to a thick paint perhaps or molasses. But once you add an amount of force, the slime resists. If you punch oobleck, it is a solid. The surface becomes impossible to penetrate. If you filled a pool with oobleck, you would be able to run across it, but standing idle you would sink. There are many videos online that put oobleck to the test: dropped, shot at, things thrown at it; punched, massaged, caressed, poured over people. It is named after a strange green, adhesive, gooey substance invented by Dr. Seuss in Bartholomew and the Oobleck, and so after years I remembered Frau Grüner and her book.

I bought a new copy of the book for this review. My original copy might still be at my parents' place in Germany somewhere, gathering dust. I turn over the red cardboard cover and start reading. Large, page-filling drawings in black, white and green, and always one or two paragraphs of text.

Bored by the eternally returning four seasons and the climate's limited diversity, King Derwin, ruler of the little kingdom of Didd, commands his magicians to come up with new weather (Dr. Seuss 1949, n.p.). The next morning it starts raining oobleck, "queer little greenish blobs". The king rejoices and orders Bartholomew, his page boy, to ring the bell and proclaim the day a holiday. Bartholomew heads to the bell tower and wakes up the royal bell ringer, but they cannot ring the bell as the oobleck, a gooey, adhesive substance, a green molasses, is stuck to it. Bartholomew, understanding the danger of the situation, begins his quest to save the kingdom. He finds the trumpeter in order to warn the people. But oobleck oozes into the trumpet and clogs it. Bartholomew tries the captain of the royal guard: in an attempt to prove his masculinity, the captain scoops up some of the oobleck with his sword and swallows it-resulting in "his mouth [...] glued shut with oobleck". Realising the responsibility to warn the citizens of Didd might lie with him, Bartholomew heads to the stables, but unsurprisingly it is too late to step outside. Everything is already covered with the strange gummy adhesive. Even the inside of the castle no longer offers safe refuge. "With an angry roar, the oobleck was suddenly hitting the palace harder [...]. Like a sinking sailboat, the whole palace was spitting leaks [...]. It was dripping through the ceilings. It was rolling down the chimneys. It was coming in everywhere [...] even through the keyholes!" The royal cook, the royal laundress, the royal fiddlers, all of Bartholomew's friends are immobilised, "flopping 
and floundering, all hopelessly stuck in the goo." In the throne room, the king, too, is covered with ooze. "His royal crown was stuck to his royal head. The seat of his royal pants were stuck to his royal throne" (ibid.). No longer rejoicing, the king commands Bartholomew to fetch the magicians to reverse the spell, but-of course-they too are stuck in oobleck. The king tries to recite the chants himself, but cannot remember all of it. In the end, the king admits his guilt and Bartholomew convinces him to use "simple words" and apologise:

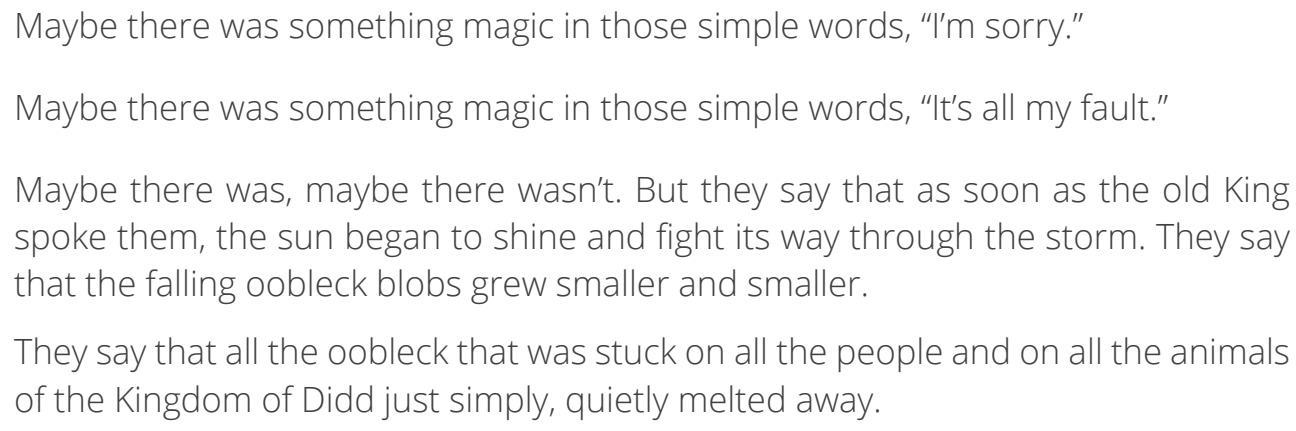

Oobleck, this apocalyptical phenomenon, is a strange substance. It drips through cracks and holes, it oozes. But it also acts like glue, sticking to things and surfaces. Its blobs vary from the size of grape seeds to that of footballs. At first, it falls like rain or snow, but is also described as hardhitting. It is flexible and stretchy, though also retracts forcefully, like a rubber band. It seems to be a thickish fluid, but also takes the form of soap bubbles. Yet no lasting damage seems to have been done, it is no corrosive or toxic substance. Its water-and-starch namesake is of a similar ambiguity, being both solid and liquid.

\section{Seussian Fantasies and Plastic Material}

Oobleck seems like a thing of science fiction and fantasy, but it is also a real, physical compound. In her book Staying With the Trouble: Making Kin in the Chthulucene (2016), Donna Haraway often thinks through notions of SF: "science fiction, speculative fabulation, string figures, speculative feminism, science fact, so far" (2). In times of global urgency and planetary entanglement, and with a wealth of bacterial, fungal and tentacular metaphors, Haraway calls for feminist leadership in imagination, thoughts and action to unravel ties of kinship and speciesism (102). In an attempt to follow her example, I will entangle myself with the oobleck for metaphorical fabulation. Science fiction as fertile speculation on social flesh. Perhaps this socio-political fabulation can become a figuration of solidarity. Indeed, my claim is that we can learn a solidarity from oobleck. That we can become politically resisting bodies by performing oobleck.

Oobleck is a substance. Yet, in Dr. Seuss's fable, it also has attributes of a being. It seems to have a telos, maybe even a will. At times it seems angry, and that anger is directed. It might be sentient, perhaps also sapient. One can make a strong assumption, at the end of the book, that oobleck is able to communicate and understand-simple-language. Once the king admits his guilt and apologises, the oobleck retreats. How the events took place exactly and why seems to be opaque to the people of Didd, but my understanding is that the oobleck made a conscious choice to 
disappear. It could thus be seen as more than an odd aggregate, but also a being, a creature, a critter. One of significant intelligence.

In an article entitled "One Life Only: Biological Resistance, Political Resistance" (2016), Catherine Malabou sets out to elaborate the thought "[t]hat a resistance to what is known today as biopower [...] might emerge from possibilities written into the structure of the living being itself" (429). Malabou hopes to activate resistance to biopolitics on a biological level: a cellular potential for radical politics. In Foucault's work, biopolitics is the application of biopower to regulate political subjects, an attempt to govern all aspects of the subjects' lives. Biopolitics thus operates through the erasure of its subject as a living being (Foucault in Malabou 2016, 429); but precisely within the subject's biology, there might lie the possibilities for insurgency, Malabou claims by looking in detail at the implications of research into epigenetics and cloning. From epigenetics she deduces that no matter how much determinism is suggested by the absoluteness of our DNA, this genetic code gets constantly interpreted and read differently through our RNA-ribonucleic acid, a molecule essential for the decoding and expression of genes. Nothing is quite as set in stone as it might appear. From cloning, and ideas of human beings reproducing and regenerating independently, Malabou takes a perspective that is at both looking forward and backward: to the future of transhumanism and to anemones hydra, bacterial lifeforms-our most distant, prehistoric relatives. The fact that this source of biopolitical resistance has never been thought is due to the antibiological bias of philosophy:

\section{Contemporary philosophy bears the marks of a primacy of symbolic life that has been neither criticized nor deconstructed. \\ Symbolic life is that which exceeds biological life, conferring meaning upon it. It refers to spiritual life, life as a "work of art," life as care of the self and the shaping of being, peeling our presence in the world away from its solely obscure, natural dimension. (431)}

It is both an interrogation of epistemology and biological science-and thereby ontology-and a call to arms. Malabou exerts that recent trajectories in biological research should keep us hopeful: she envisions a new materialism, which might reinstate the simultaneity of symbolic and biological life (438), the "fact of living and the elaboration of a mode of being" (433). Becoming conscious of the biological potential, of "[w] hat is most material and most vital in bodies" (433), could thus spark a political resistance. Proposing that we should become or perform oobleck-as I will in just a moment-seems like it is fully prioritising the symbolic over the biological. There could hardly be a proposition more symbolic. But oobleck is very much material and learning from it is grounded in the real. And perhaps this kind of speculative fiction, this Seussian fantasy, might also be a way of diluting the dichotomy of the biological versus the symbolic. After all, a bit of SF might be a necessary ingredient in "making kin" (see Haraway 2016) as well as in the "development of a new materialism" (Malabou 2016, 438).

Oobleck, in Bartholomew and the Oobleck, might well be an intelligent, sentient being. An agent in the story, not only an event. As such, we might follow Haraway's call for inter-species solidarities in 
the Chthulucene. But oobleck, the non-Newtonian fluid, is also a chemical compound. Malabou invites us to search the cellular, the microscopic, and the most material for political potentials. And we could do just that. We should follow Malabou's and Haraway's example when it comes to cornstarch and water. Can we become-or become with-oobleck? Is there a potential for political resistance in the gooey compound? I believe so.

One part water, two parts cornstarch. A simple recipe for political resistance. Could we become oobleck, or oobleck-like? We would be at once a solid and a liquid, defying Newtonian laws. When met with force, we become hard. A resisting solid. If engaged slowly and with care, we soften. A compliant liquid. As oobleck, we do not have an internal stability, we are spineless. Each time we take shape might look different. As shapeshifting oobleck, we are hard to describe and impossible to pin down. We might cover or veil something, we might lubricate, we might stick. We might spill, flow, drip, and slip. We can fill any crevice, cover any object, leak through even the smallest loophole. Could we become bodies that are only water and starch? The German word for starch is Stärke, which also means strength or fortitude. To become entirely comprised of water and strength might not be a bad goal.

Though the call to become oobleck is a symbolic one, it might be less abstract than it appears at first glance. In What Should We Do with Our Brain? (2008), Catherine Malabou works out a political and ontological position based on the assertion that we are "plastic". Malabou develops the Hegelian notion of plasticity, which contends that human subjectivity is always both passively formed and actively forming. She does so by drawing from present neuroscience and neurobiology - which speaks of the plasticity of the brain-as well as the tripartite meaning of plastic-being formed, giving shape, and possibly exploding. She ties the scientific insight of our brain's plasticity to a metaphysical elaboration of the human subject and simultaneously establishes a powerful political metaphor. In our current capitalist society, what is being continuously postulated is a "flexible human subject," flexible about her schedule, availability, wage, geographical location, skills, profession et cetera. But flexibility only carries one of the meanings of plasticity-that of receiving form. "Flexibility is plasticity minus its genius" (12). What this ideological portrayal of the human does away with in plasticity is both our creative potential to give shape and our explosive potential to negate and destroy form. Gaining consciousness of our plasticity thus carries tremendous political potential for Malabou, even if her call to arms always operates somewhat on the metaphorical. Elsewhere, Malabou further expands, "[p]lastic, if you look it up in the dictionary, means the quality of a matter, which is at the same time fluid but also resisting" (Malabou in Vahanian 2008, 6). Our plasticity already holds the key to oobleck performativity.

One third water, two thirds starch. In cooking recipes, starch is used as a binder. In political resistance, oobleck performativity might do the same, enabling us to build stronger solidarities. We could mix better and hold together. Furthermore, water and starch help make a single mass, resisting individuation and the risk of being singled out in a protest. Mixture (of a dough for example) and crowd (of people) are one word in German: Masse. Becoming oobleck, performing social dough. 
In the face of what many, including myself, perceive as a suffocating capitalist system, exploitative institutions of all kinds, a precarisation of everyday life, patriarchal, racist and ableist hierarchies and so many other forms of domination, we are constantly in need of finding effective modes of resistance, that also enable systems of mutual care. Especially in the current moment, when political structures seem unable to answer economic, ecological and social crises, when the legitimacy of representative democracy in its various forms is being questioned, and when tried and trusted methods of political engagement and protest seem no longer adequate, we are bound to look for new solutions. The Institute for Precarious Consciousness (2014) argue that each phase of capitalism comes with a dominant reactive affect, which in turn necessitates different strategies of resistance, and that contemporary strategies of resistance no longer answer the current reactive affect of capitalism (1-2). Theorists such as Judith Butler draw out how we might utilise our vulnerability as precarious bodies. Coalitional politics and bodily vulnerabilities might inform one another to bring about ethical and political norms (2015a, 123). In this sense, it might be time to look for ways of becoming vulnerable resistants:

\begin{abstract}
A group acting together has to be supported to act, and this takes on special meaning when the action takes place increasingly as a way of demanding enduring support and the conditions of livable life. It could sound as no surprise that the bodies gathered in social movements are asserting the social modality of the body. This can be a minor way to enact the world we wish to see, or to refuse the one that is doing us in. Is this not a form of deliberate exposure and persistence, the embodied demand for a livable life that shows us the simultaneity of being precarious and acting? (Butler 2015a, 153)
\end{abstract}

Two parts starch and one part water. Oobleck holds a certain performativity which I find inspiring for political tactics. We would hold properties showing an unusual behaviour. A person could run across us without sinking. Becoming oobleck, we might thus constitute the ground for revolutionary charges as well as lines of flight. When struck or hit, oobleck is a solid: we negate and resist. When slowly interacted with, touched, caressed, delved into, oobleck is a liquid: we comply and engage. A non-Newtonian fluid: another step on our path away from the dialectics of Enlightenment. Is oobleck what a contemporary vulnerable resistant could look like? Performing oobleck, we would hold the power to absorb care whenever we desire, and resist force whenever we need to.

Was Frau Grüner teaching me about political performativity as a vulnerable resistant when she passed on Bartholomew and the Oobleck? Likely not. And yet, reciprocity, share-economies, neighbourly solidarities and mutual support are all little but very important aspects of political solidarity. On a very small scale, passing on books, watering plants, and feeding the cat are examples of what Judith Butler calls "enduring modes of dependency and interdependency" (Butler 2015b, 8) and are small nods to the fact that the politics and labour of care expand beyond the human subject. And what did Dr. Seuss have in mind with the oobleck, when he wrote the story? I doubt that his fabulation was one for political resistance, either. Certainly, that is not how I 
understood it, when I first read it. I cannot really remember what I thought the story meant. But I suppose what I took from it was a moralising conclusion: the King is urged to apologise and admit his guilt in simple language in order for the "just punishment" to stop. A story about karma; and about man's hubris, tempering with things he has no authority over. From today's perspective, it could also be a fable about environmental harm and our ecological impact, as we continue to affect the climate and weather of this planet through unsustainable consumption, resource extraction and lifestyles. A work of and on the anthropocene. But now, years after first browsing the book, I take something very different from it.

What if the oobleck is actually the story's protagonist? Dr. Seuss tells the story from the perspective of Bartholomew. We follow his adventure through the castle, trying to fend off the catastrophic results of his ruler's actions. It is a sequel to The 500 Hats of Bartholomew Cubbins. Signs are pretty clear as to who the protagonist of the story is meant to be. Bartholomew Cubbins works as a page boy for King Derwin, ruler of Didd. His responsibilities however shift as the story develops, from running errands for the king to trying to save the kingdom from the impeding oobleck. Though he does eventually shake up the hierarchical power structures a little bit by confronting the king and urging him to take responsibility and show remorse, he does not generally question the constituted structures of the state or its ruler's powers. Should we really side with character who is fully part of the ruling forces and who is concerned, throughout the story, mainly with restoring the monarchy to its previous status quo? When I was reading Bartholomew and the Oobleck again, I found myself siding more and more with the inexplicable weather occurrence, the ooze throwing the kingdom and its king into peril. The story presents us with a sovereign clearly abusing their might and also with an effective strategy of resistance. The oobleck performs this resistance. It manages to slow the kingdom down to a halt. It stuns the king, his army, it infiltrates the castle, jams its communication technologies.

I read the eventual unexplained disappearance of the oobleck not as a defeat. The little kingdom only gets reinstated to normality after the oobleck chooses to disappear. The people never quite find out why the oobleck melted away. Perhaps because its intelligence, language, and behaviour are too alien to them. Nonetheless, I believe that Dr. Seuss is suggesting that the king's apology to the oobleck was necessary. Oobleck showed itself satisfied and took mercy on the kingdom. But during its short onslaught on the kingdom, the oobleck performativity is able to suspend the state apparatus in its entirety: the constituted powers are unable to respond or retaliate.

This complete subversion of the state's infrastructure is precisely what Giorgio Agamben has in mind when he talks about "inoperativity." In 'What Is Destituent Power?' Agamben names inoperativity as the primary tactics of destituent power.

\footnotetext{
Inoperativity does not mean inertia, but names an operation that deactivates and renders works (of economy, of religion, of language, etc) inoperative [...]. This essential inoperativity [...] is not to be understood as the cessation of all activity but as an activity that consists in making human works and productions inoperative, opening them to a new possible use. (Agamben 2014, 69)
} 
In opposition to the common political paradigm of constituted power versus constituent power, as championed by Toni Negri and others, Agamben proposes the post-anarchist notion of destituent power, necessitating completely new political strategies, instead of resorting to "a violence that establishes and constitutes the new law" (70). Agamben remains vague on what a destituent power looks like, but oobleck might provide one way of thinking this notion. It performs an operation, rendering the works and infrastructure of the Kingdom of Didd inoperative. Its royal bell, its trumpeter, its royal guard, stables, cooks and even the king itself become deactivated.

The performativity of oobleck should inspire our political tactics. Two thirds starch and one third water: a recipe for inoperativity. Dr. Seuss's oobleck teaches us how to render the state apparatus inoperative, deactivate its infrastructure, suspend its violence. The "actual," chemical oobleck teaches us to repel force whenever needed while accepting care whenever desired. Oobleck politics is both internal and external.

In 'Resist Like a Plant! On the Vegetal Life of Political Movements' (2012), Michael Marder theorises anarchic tactics on the basis of vegetal ontology (29). Marder sees many benefits in "resisting like a plant": rather than the simple "grassroots" metaphor, it might allow to change our understanding of key notions such as growth, networks, decay. Marder is also able to elaborate notions of violence and non-violence by offering what he calls "ontological violence" (25). Plants, often seen as a symbol of nonviolence, actually display a significant degree of force in their occupation of space, self-assertion through growth, etc. Oobleck to me seems to display a similar ontological violence, a will-to-power, or a "slow violence" (Nixon 2013). Marder further ponders the political implications of what it means "to be plastic enough to metamorphose into a different state" $(2012,28)$. Political movements with a vegetal ontology promise "to be, at the same time, pliable and rigid" (30). But we have also learned from Malabou that this plasticity is already an inherent component of our human ontology. And I would argue that "resisting like oobleck" might be an even more successful tactic. Marder takes from the vegetal ontology a rhizomatic, acephalic structure that makes protest movements hard to grasp or address. Without clear structures or a "head" of the movement, vegetal protests such as Occupy Wall Street are inherently an-archic, which holds both prefigurative and tactical promises. While rhizomatic might not quite be the right term, Oobleck too is acephalic, hard to pin down, and decentralized. It too expresses an inherent anarchism, as well as an almost alien swarm intelligence.

Plant resistance operates through a politics of space, "resist[ing] on the basis of radical passivity" (27). I would argue, that this passivity is not "inertia," no "cessation of all activity," as Agamben would delineate from inoperativity $(2014,69)$. And indeed, Marder points out that this radical passivity transgresses the common opposition between active and passive and instead shows a highly political character $(2012,27)$. It thus closely resembles inoperativity and might well be regarded as a part of the destituent vocabulary. But the two are by no means identical. In my opinion, radical passivity cannot necessarily claim to render other operations inoperative. Neither does it inherently constitute a ground for new possible use. We can see this in the example of Occupy that Marder employs: though redefining engagement with public space and the modes and bodies of resistance, Occupy Wall Street did not render its target inoperative. No doubt Wall Street was 
inconvenienced by the Occupy protests, but it never ceased to operate. While the radical passivity of the movement does assert Marder's point of freedom of expression and freedom of assembly coinciding, and thus fundamentally shaping the movement's ontology, it falls short of performing inoperativity in the Agambian sense. I see in radical passivity a promising internal mode, giving the movement its structure, and in inoperativity a more effective external tactic of addressing directly the constituted structures. Oobleck performs its political resistance through a similar radical passivity, whereby its mere existence in the space becomes a political act-but it goes further than Occupy and Marder's ontological violence of a radical passivity by not only inconveniencing but fully deactivating stately power structures. It has attributes of inoperativity as well as radical passivity. Oobleck seems extremely well suited at calling into question both: aggregate states and sovereign states.

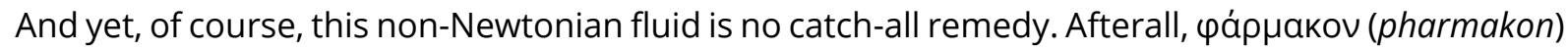
is a term with two opposing meanings: poison and antidote. Arguably, states themselves have become far more oobleck-like. In "Postscript on the Societies of Control" (1992), Gilles Deleuze draws out how we have moved from disciplinary societies, a coin termed by Michel Foucault, to societies of control. Having moved away from a disciplinary social structuring of enclosures, we are now faced with different apparatus of control: Enclosures are molds, distinct castings, but controls are a modulation, like a self-
deforming cast that will continuously change from one moment to the other, or like
a sieve whose mesh will transmute from point to point. (Deleuze 1992, 4)

Since then, Deleuze's predictions can perhaps be perceived as more relevant. We are experiencing governing powers as constantly fluctuating and modulating. We are dealing less and less, according to Deleuze, with a dichotomy of mass and individual and instead with the "dividual" and its "samples, data, markets, or 'banks"' (5). What can be observed is an oobleck-like veil that infiltrates and covers all aspects of life. Similar changes in state operations can be observed in urban warfare, with Eyal Weizman (2017) pointing out how Israeli military have been subverting architecture and urban design by moving through the walls of apartment buildings instead of windows and doors: "a conception of the city not just as the site, but as the very medium of warfare-a flexible, almost liquid matter that is forever contingent and in flux" (186). In the age of dataveillance, with an evergrowing proportion of our activities taking place online, Deleuze seems to be suggesting more and more ad hoc regulation and surveillance. Through this growing individualisation of governance, collective performances such as an oobleck solidarity might prove increasingly difficult. Furthermore, as Isabell Lorey (2015) convincingly argues, the very essence of modern government is the management of insecurity, whereby subjects find themselves in a constant state of precariousness, yet never quite at the point of insurrection (2). If this is the case and we find ourselves at a threshold of precarity, our margin of error when becoming vulnerable resistants is discouragingly slim.

But as bleak as it may look, we might want to return to Deleuze once more, when he resolutely concludes: "there is no need to fear or hope, but only to look for new weapons" $(1992,4)$. 


\title{
Oobleck Movements
}

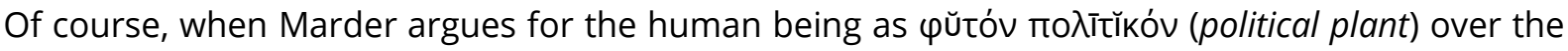
$\zeta \tilde{\omega}$ ov по入і̄ĩ̌óv (political animal), he knows that this is not literally the case $(2012,28)$.

\begin{abstract}
Purely vegetal beings do not protest, do not set themselves against anything, do not negate-symbolically or otherwise-what is. But if we act as though we were them, following a useful theoretical and practical fiction grounded in the vegetal heritage of the human, we would need to follow a non-possessive, nonappropriative way of being, resonating, at once, with the conclusions of botany and with the image of post-metaphysical ethical subjectivity. We would, consequently, repudiate the ideal of sovereign and decisive action, directed by a rational, conscious or self-conscious, individual or collective subject and, instead, nurture the horizontally and an-archically growing grassroots that crop up wherever protest tents are pitched in the shadow of skyscrapers. (26)
\end{abstract}

In a similar vein, Haraway postulates the importance of SF in theory and practice, and Malabou uses our brain's plasticity as the basis for courageous political imaginary. My project is using the same methodology: we should perform oobleck as an inspiring tactic of becoming vulnerable resistants.

But I believe that oobleck is not only a tactical fabulation, but actually quite close to a description of recent protest movements that seem to have moved away from how protests were constituted in the past. Marder's "Resist Like a Plant!" offers a fresh take on the Occupy movement. With Occupy, he says, "freedom of expression and freedom of assembly merge into one: physical presence (or, rather, co-presence) expresses, without representing anything, in the most embodied sense of expression imaginable, the demand for a different world-order" $(2012,25)$. Oobleck shares with the Occupy protesters that their mere presence holds the potential for calling the legitimacy of the rulers into question. But I would add that not only do protests like Occupy Wall Street or the French gilets jaunes (yellow vests) merge freedom of expression and freedom of assembly, but on its most fundamental, ontological level, what is being exercised is their right to exist. And this is where oobleck as an interpretative framework can go one step further than vegetal ontology, as it is already its existence itself, ahead of its public assembly, that is a political act; there is an ontological demand written straight into the fabric of Oobleck, which insists on a certain behaviour towards it: force will be rejected, care will be accepted.

Many commentators were disturbed by Occupy's shapeshifting physicality: no leaders or clear messages made it hard for officials to engage. Without an apparent order or structure, some like Chantal Mouffe (2016) argued that Occupy Wall Street was unable to become a player in the political landscape, make demands or compromises, be addressed or understood. But exactly this, says Marder, is its anarchic potential: the movement remained acephalic and rhizomatic. The protests bestowed Wall Street with a new kind of colour, aesthetic, haptic and affect. People were unsure about what exactly had hit them and why. Oobleck, too, is acephalic. It takes the king a long time to find the right way to communicate with it. Its goals and demands are opaque, its exact 
reasons for eventually giving way remain a mystery. But on top of its vegetal ontology, Occupy, in its many iterations, could be understood through oobleck performativity: the protestors covered public space, slowing life down on it, sticking to the streets of Manhattan, and many other places across the globe, like glue.

One part water, two parts starch. Oobleck provides us with an inspiring recipe for shapeless, headless, rhizomatic, alien, resisting, vulnerable, inoperative, passive spatial resistance. It provides us with a subversive tactic on how to respond to a sovereign abusing their powers. It is a timely recipe, the performativity of which we can see implemented in recent protest movements. Occupy, especially in the US, is a good example, but it also applies aptly to the gilets jaunes movement in France. As a complex and ambiguous movement, it is hard to theorise. Many on the left are unsure whether to reject it or show solidarity. It seems as if a common language has yet to be found. The movement, equally made up of rural Front National voters and left and anarchist protesters and rioters, is calling into question the legitimacy of the government. The protest seems shapeshifting, cacophonous, and acephalic. One of its major tactics is that of slowing down. My friend Stephen Wright told me an anecdote from his village in France where some yellow vests were crossing the street at such microscopic speed that they brought the whole intersection to a standstill. They were rendering the state's infrastructure inoperative: a destituent strategy, gluing cars, trucks and police vehicle to the ground, like Seussian oobleck. They were doing nothing illegal, just crossing the street. But in the process of doing so in such a decelerated fashion, they subverted the legal procedure of crossing a street into a "radical passivity." In the same way, King Derwin's demand for new weather was followed, but in a way so subversive that it called his sovereign legitimacy into question. Incidentally, the French protests, sparked by a rising diesel tax, is also about a sovereign trying to alter the weather. The gilets jaunes, whatever else we make of their motivations or politics, are already performing oobleck.

Learning about the non-Newtonian fluid and reviewing Dr. Seuss' children's book, we can be inspired by oobleck. It offers us a recipe to simultaneously absorb care and reject force. It teaches us how to be the ground of revolutionary charges and lines of flight. It offers an ability to organise in a unifying way, where we become one shapeshifting, headless substance that drips and slips, that spills and flows. As oobleck, we can occupy spaces, rendering whole states inoperative. We can glue armies to the ground, silence alarm bells, and frighten kings in their throne rooms.

Matthew Goulish (2000) speaks of glass to argue that the state of matter of some things has to be perceived as ambiguous with the inclusion of time. Both solid and fluid. Both pliable and rigid. Over time, criticism might become art (44). With the inclusion of time, Bartholomew and the Oobleck reveals itself to be both: a children's story and a recipe book for political resistance. 
${ }^{1}$ For their indispensable help and feedback on this essay I want to thank the entire cohort of artists/researchers of the DSRA "Document and Contemporary Art," le bi-corporalité, and cher collègue. Sharing time and space through readings, seminars, and late nights has been an incredible enrichment. For his anecdote on the gilets jaunes, Stephen Wright; for pointing out "slow violence," Thomas Guillot. For always finding the time and clear, pragmatic suggestions, Andrew Culp. For teaching me to edit, Patricia Sazani. For deep, critical, and reparative feedback, Effy Morris.

\section{Works Cited}

Agamben, Giorgio. 2014. "What Is Destituent Power?" Environment and Planning D: Society and Space 32 (1): 65-74. https://doi.org/10.1068/d3201tra

Butler, Judith. 2015a. Notes Toward a Performative Theory of Assembly. Cambridge, MA: Harvard University Press. https://doi.org/10.4159/9780674495548

2015b. Senses of the Subject. New York: Fordham University Press.

"Cathedral Glass Myth Shattered." 1998. Science, May 12. https://www.sciencemag.org/news/1998/05/cathedralglass-myth-shattered

Curtin, Ciara. 2007. "Fact or Fiction? Glass Is a (Supercooled) Liquid." Scientific American, February 22. https://www.scientificamerican.com/article/fact-fiction-glass-liquid/

Deleuze, Gilles. 1992. "Postscript to Societies of Control." Translated by Martin Joughin. October 59: 3-7.

Dr. Seuss. 1949. Bartholomew and the Oobleck. New York: Random House.

Goulish, Matthew. 2000. 39 Microlectures in the Proximity of Performance. New York and London: Routledge.

2015. "Palinode of Glass." Performance Research 20 (5): 132-33. https://doi.org/10.1080/13528165.2015.1095987

Haraway, Donna. 2016. Staying With the Trouble: Making Kin in the Chthulucene. Durham, NC: Duke University Press. https://doi.org/10.1215/9780822373780

Institute for Precarious Consciousness. 2014. We Are All Very Anxious. Self-Published.

Lorey, Isabell. 2015. State of Insecurity. London: Verso.

Malabou, Catherine. 2016. "One Life Only: Biological Resistance, Political Resistance." Critical Inquiry 42: 429-38. https://doi.org/10.1086/685601

2008. What Should We Do With Our Brain? New York: Fordham University Press.

Marder, Michael. 2012. "Resist Like a Plant! On the Vegetal Life of Political Movements." Peace Studies Journal 5 (1): $24-$ 32.

Mouffe, Chantal. 2016. "In defence of left-wing populism." The Conversation, April 29. http://theconversation.com/indefence-of-left-wing-populism-55869

Nixon, Rob. 2013. Slow Violence and the Environmentalism of the Poor. Cambridge, MA: Harvard University Press.

Vahanian, Noëlle. 2008. "A Conversation with Catherine Malabou." Journal for Cultural and Religious Theory 9 (1): 1-13.

Weizman, Eyal. 2017. Hollow Land: Israel's Architecture of Occupation. London: Verso. 


\section{Biography}

Josh Widera is one of six members of The Doing Group, an international collaborative performance group concerned with the process of 'doing'. Projects of the Glaswegian experimentalists have taken multiple forms and seek to explore the limits and depths of artistic research. Josh graduated from the University of Glasgow with an MA with Honours of the First Class in Politics and Theatre Studies and from the California Institute of the Arts, Los Angeles with an MA in Aesthetics \& Politics. He is a Fulbright Scholar and supported by the Studienstiftung des Deutschen Volkes and the Lillian Disney Scholarship.

(c) 2019 Josh Widera

(c) (1) Except where otherwise noted, this work is licensed under a Creative Commons Attribution-

(c) ${ }_{\text {EY NC SA }}$ NonCommercial-ShareAlike 4.0 International License. 